\title{
Luther en Calvyn se siening van seksualiteit
}

\author{
P.J. de Bruyn
}

Departement Dogmatologie en Ekklesiologie

Potchefstroomse Universiteit vir $\mathrm{CHO}$

POTCHEFSTROOM

\begin{abstract}
Luther and Calvin's view on sexuality

Until the time of the Reformation in the sixteenth century the Roman Catholic view of sexual intercourse was that it is sinful in itself, but that this specific sin is pardonable when committed within a marital relationship for the purpose of procreation. At the Council of Trente it was determined that intercourse was not allowed within the three days preceding Holy Communion. Luther's view, and to a great extent also that of Calvin, was that the act of sexual intercourse as such is sinful. Within a marital relationship, however, whether for the purpose of procreation or for the satisfaction of the sexual needs of husband and wife, this sin is pardonable - according to Luther and Calvin's views. Luther stressed that participation in Holy Communion did not limit married people in this regard: moderation was the only norm. Both Luther and Calvin strongly rejected celibacy.
\end{abstract}

\section{Inleiding}

In die periode na ongeveer 1950 het daar by die algemene publiek, veral in die Westerse wêreld, so 'n ingrypende verandering gekom wat hulle beskouing oor en belewing van seksualiteit betref, dat dit tereg as 'n seksuele revolusie bestempel is (Barczay, 1967:7-9; Paloczi-Horvath, 1967:7; Huntemann, 1971:7-15). Voorhuwelikse geslagsgemeenskap, buite-egtelike seks, die saamwoon van ongetroudes, homoseksualiteit, egskeidings, ensovoorts wat voor 1940 sterk afgewys is, is tans aan die orde van die dag (Rinzema, 1972:8-18). Een van die belangrikste oorsake van die seksuele revolusie is geleë in die onnatuurlike onderdrukking van 
die seksuele lewe wat veral in die Victoriaanse tyd 'n hoogtepunt bereik het. Hierdie uiterste het 'n reaksie ontlok en die weg gebaan na 'n uiterste ongebondenheid (Kraft, 1968:55; Mace, 1970:40-66, 74-78; De Bruyn, 1982: 102-105, 128-129).

Die vraag ontstaan nou: Hoe moet die standpunte en uitsprake van die Hervormers in hierdie verband gesien word? Is die seksuele revolusie die uiteindelike konsekwensie van hulle sienings, of het hierdie siening bygedra tot die vorming van die negatiewe houding oor seksualiteit sodat die seksuele revolusie ook 'n reaksie teen hulle sienings en invloed was?

In hierdie artikel sal veral gefokus word op die twee Hervormers wat die grootste invloed uitgeoefen het, naamlik Luther en Calvyn. In verskeie opsigte is daar feitlik algehele ooreenstemming ten opsigte van hulle sienings van seksualiteit, maar omdat albei nie dieselfde invloedsfeer gehad het nie en daar soms tog verskille tussen hulle was, al is dit net wat aksente betref, is dit tog gerade om hulle apart te behandel.

Eers sal aangedui word wat die siening van seksualiteit in die RoomsKatolieke Kerk was tot en met die Hervorming. Daarna sal die beskouings van Luther en Calvyn agtereenvolgens behandel word. Aan die einde sal 'n beoordeling gegee word.

\section{Die Rooms-Katolieke Kerk se siening van seksualiteit}

\subsection{Die monsterverbond tussen die Christendom en die heidendom}

Reeds uit die Nuwe Testament is dit duidelik dat daar gedurende die eerste eeu van die Christelike kerk 'n ontsettende sedelike verwildering in die Romeinse Ryk geheers het (Rom. 1:18-32).

Hierdie sedelike verwildering is deur Paulus daaraan toegeskryf dat die heidene God se openbaring teen hulle beterwete verwerp het (Rom. 1:18, 19, 32). Histories beskou, was die oorsaak van hierdie sedelike verwildering die invloed van die Griekse leefwyse en denke (Bailey, 1959:4). Teen hierdie sedelike verwildering het die Christendom in sy eerste jare in heftige verset gekom (Rom. 1; 1 Kor. 5, 6). 
Dit was egter nie net die Christene wat teen die verwildering in verset gekom het nie. Daar was ook, wat Rinzema (1972:68) noem, die "edele heidene" wat ernstig daaroor verontrus was en iets daaraan wou doen (Bailey, 1959:4). Hierdie "edele heidene" was die woordvoerders van die Stoïsyne en Neo-Platoniese filosofie (Bailey, 1959:4; Mace, 1970:43).

Saam met die "edele heidene" het die Christene die stryd teen die sedeloosheid aangeknoop. Op dié wyse het daar, volgens Rinzema (1972:68), 'n monsterverbond tussen die Christene en die heidene tot stand gekom. Die Christene en heidene het dieselfde doel voor ö̈ gehad, maar het opgetree vanuit verskillende agtergronde en motiewe. Die Christene het teen sedeloosheid gestry omdat hulle daarin 'n verwerping van God en sy gebod gesien het, maar die heidene het dit gedoen vanuit die asketiese tendense van die Stoïsyne (Bailey, 1959:4, 5) en veral vanuit die dualisme van die Neo-Platonisme.

Plato se siening in hierdie verband het daarop neergekom dat die denkende siel goddelik was, terwyl die liggaam daarteenoor as veragtelik beskou is. In die Neo-Platonisme is hierdie dualisme, hierdie skeiding tussen siel en liggaam, nie net oorgeneem nie, maar dit is vereenselwig met die teëstelling goed en kwaad (Mace, 1970:43). Alles wat met die siel te doen het, is as goed beskou, maar alles wat met die liggaam te doen het, is as sleg veroordeel bloot omdat dit liggaamlik is.

Pogings is aangewend om genoemde Hellenistiese dualisme in die Bybelse gedagtes van siel en liggaam, goed en kwaad in te dra (Miles, 1972:210211) en hierdie pogings was nêrens so suksesvol as op die terrein van die kerk se houding teenoor seksualiteit nie (Cole, 1955:8).

As gevolg van hierdie invloed van die monsterverbond tussen Christendom en heidendom was die Christelike kerk in sy beskouing en beoordeling van die seksuele vasgevang in die greep van hierdie dualisme. Dit het daartoe gelei dat daar by die Christene 'n minagting vir die liggaamlike en in die besonder vir die seksuele ontstaan het. So het die antiseksuele tendens in die Christelike kerk tot stand gekom.

\subsection{Die tydperk van die kerkvaders (ca. 150-450)}

Hierdie antiseksuele tendens het gelei tot 'n minagting van alle seksualiteit by die kerkvaders. Origines (ca. 185-245) het homself op 'n vroeë leeftyd 
laat kastreer omdat, volgens hom, toewyding aan die diens van die Here alleen werklik tot sy reg kan kom as die geslagsdrif geëlimineer is (Brink, 1977:20; Deschner, 1980:252). Augustinus (354-430) se siening was dat geslagsgemeenskap wesenlik sondig is, maar verskoonbaar as dit binne die huwelik met die oog op voortplanting plaasvind (1971a:402, 404; 1971 c:250), en daarom moet sodanige geslagsgemeenskap nie as sonde beskou word nie. Geskied dit egter binne die huwelik bloot uit lus en begeerte, is dit beslis sonde (Augustinus, 1971a:400, 404; 1971b:262, $263 ; 1971 \mathrm{e}: 387$ ), maar dan tog vergeeflike sonde (Augustinus, 1971 a:402; 1971b:263; 1971d:270).

Augustinus se siening van seksualiteit is van groot belang omdat dit in die eeue na hom 'n beheersende invloed op die standpunt van die kerk in dié verband gehad het (Cole, 1955:60; Bailey, 1959:59; Deschner, 1980:253). Die gevolg hiervan was dat die kerk nie net aan die ongehude staat voorkeur gegee het nie, maar dit ook hoog opgehemel het (Hieronymus, 1912:30; Bailey, 1959:98). Daarteenoor is die huwelik - hoewel dit as 'n instelling van God verdedig is - gedegradeer tot die laagste plek in die gelowige se roepingsvervulling. Daarby kom ook nog dat die aansien en mag wat die persone in die ongehude staat in die kerk verkry het, tot gevolg gehad het dat ongetroudes voortaan aan getroudes voorgeskryf het hoe hulle binne die huwelik behoort te lewe (Rinzema, 1972:69).

Dit is logies dat daar in hierdie beskouing geen ruimte gegun is vir buiteegtelike geslagsgemeenskap nie. As geslagsgemeenskap binne die huwelik al as sondig beskou is, veral as dit nie geskied met die oog op voortplanting nie, is dit as ' $n$ baie groter sonde beskou as dit buite die huwelik plaasvind.

\subsection{Die Middeleeue (ca. 600-1400)}

Thomas van Aquino ${ }^{48}$ (1225-1274) kan beskou word as die grootste figuur in die kerklike lewe tydens die Middeleeue. Deur sy geskrifte, en in die besonder deur sy Summa Theologica, sou hy eeue lank sy stempel op die amptelike standpunt van die Rooms-Katolieke Kerk afdruk.

Na hom sal verder as Thomas verwys word 
Uit sy siening van seksualiteit is dit duidelik dat hy, soos feitlik al sy voorgangers in die Christelike kerk sedert die tweede eeu na Christus, uiters negatief teenoor geslagsgemeenskap gestaan het en dit beskou het as iets wat inherent sleg en sondig is, hoewel die sonde verskoon word as dit geskied met die oog op voortplanting. Ook was dié sonde verskoonbaar as dit hoerery, nie deur die betrokke persoon self nie, maar deur die ander party in die huwelik, voorkom (Thomas, 1948:2740, 2741). Omdat voortplanting op geen ander wyse kan geskied nie, is geslagsgemeenskap eintlik deur hom as 'n noodsaaklike kwaad beskou. Hy sê uitdruklik dat geslagsgemeenskap nie 'n wesenlike, integrerende deel van die huwelik is nie (Thomas, 1948:2718).

Al het Augustinus se beskouing oor seksualiteit 'n sterk Platoniese aard en dié van Thomas 'n onmiskenbare Aristoteliaanse aard met die klem op die rasionele, is daar in praktyk min verskil in hulle beskouing en beoordeling daarvan.

\subsection{Die Konsilie van Trente, 1563}

Volgens die Konsilie van Trente is geslagsgemeenskap slegs geoorloof binne die huwelik; tog is seksuele genot beskou as gevaarlik en onversoenbaar met die diens van die Here. Daarom was geslagsgemeenskap vir die geestelike stand geheel en al verbode en vir gewone lidmate ontoelaatbaar minstens drie dae voor die viering van die Nagmaal (Catechism of the Council of Trent, 1947:355).

\section{Luther (1483-1546) se siening van seksualiteit}

\subsection{Luther se siening van geslagsgemeenskap as sodanig}

In teëstelling met Thomas van Aquino was Luther (1962:34) daarvan oortuig dat geslagsgemeenskap 'n onmisbare deel van die huwelik is (vgl. 3.2). Desondanks kom hy egter nie los van die siening van Augustinus en Thomas dat geslagsgemeenskap wesenlik sondig is nie. Dit blyk uit 'n verskeidenheid van sy geskrifte.

In geslagsgemeenskap is daar volgens Luther (1959b:365) 'n inherente sonde en dit kan ook nooit plaasvind sonder sonde nie (Luther, 1962:49; 1973:26) omdat dit immers ' $n$ uiting van die bose lus van die sondige natuur is (Luther, 1966:10). Volgens Luther het die huweliksbed nie veel 
wat rein is nie (Luther, 1959b:364), want geslagsgemeenskap vind plaas weens die drang van die mens se bose lus (Luther, 1966:8). Hy vereenselwig geslagsgemeenskap dermate met sonde dat as hy die (eerlike en opregte) ongehude staat met die huwelik vergelyk, hy eersgenoemde identifiseer met kuisheid (Luther, 1973:16,17). As die ongehude staat egter met kuisheid geïdentifiseer word, beteken dit dat die huwelik wesenlik onkuis en daarom sondig is, natuurlik omrede die geslagsgemeenskap wat daarin plaasvind (Luther, 1959b:364).

\subsection{Luther se siening van geslagsgemeenskap in die huwelik}

Hoewel geslagsgemeenskap wesenlik sondig is, is dit 'n sonde wat verskoon word as dit binne die huwelik plaasvind; in hierdie omstandighede sien God die sondigheid daarvan nie raak nie (Luther, 1959b:365). Luther (1962:49) stel dit so: geslagsgemeenskap is nooit sonder sonde nie, maar in sy genade verskoon God die sonde omdat $\mathrm{Hy}$ self die huwelik ingestel het. Ondanks die sonde hou $\mathrm{Hy}$ al die goeie in stand wat $\mathrm{Hy}$ aan die huwelik verbind en daarin geseën het (vgl. ook Luther, 1966:12). Van die wesenlike sondigheid van geslagsgemeenskap wat binne die huwelik plaasvind, sê hy (Luther, 1959b:365) dat getroude mense daarvan verskoon word. God sal hulle geslagsgemeenskap nie as onrein of as sonde beskou nie ondanks die inherente sonde daaraan verbonde. Elders (Luther, 1966:10) verklaar hy dat die bose lus van die sondige natuur, wat by niemand ontbreek nie, ' $n$ huweliksplig is en nie verkeerd is wanneer daaraan uiting gegee word binne die huwelik nie.

Sedert die sondeval is die doel van die huwelik ook nie slegs dat man en vrou in 'n verhouding van maats vir mekaar 'n hulp moet wees en kinders moet voortbring nie, want sedert die sondeval is die huwelik ook besoedel met bose lus. Nou, na die sondeval, begeer die man en die vrou mekaar nie net ter wille van kameraadskap en om kinders te verwek nie - vir welke doeleindes die huwelik alleen ingestel is - maar ook vanweë die drang van die mens se bose lus, wat bykans net so 'n sterk motief is (Luther, 1966:8). Die gevolg hiervan is voor die hand liggend: die huwelikstaat is nie langer rein en sonder sonde nie (Luther, 1966:9). Dit is egter hierdie sonde wat aan die derde doel van die huwelik, naamlik om mekaar wedersyds teen ontug te skerm, verbonde is, wat verskoon word as geslagsgemeenskap binne die huwelik plaasvind. 
Hierdie siening van Luther lei noodwendig daartoe dat hy aan die huwelik die karakter van medisyne of 'n hospitaal vir siekes toeken. Hy sê dat brandende seksuele begeerte 'n mens sal verteer tensy hy dit help en beheer deur die regte medisyne, naamlik die huwelik. Ook Paulus verbind die brand van begeerte aan almal wat kuis wil lewe maar nie die gawe van onthouding het nie en gee die medisyne van die huwelik as voorskrif daarvoor (Luther, 1973:26,27). Oor die huwelik as hospitaal verklaar hy (Luther, 1966:9) dat die drang van die sondige natuur so sterk en brandend geword het dat die huwelik vergelyk kan word met 'n hospitaal vir ongeneeslikes wat dié wat daarin is daarvan weerhou om in groter sonde te val.

Omdat geslagsgemeenskap dan volgens Luther wesenlik sondig is en die sonde slegs verskoonbaar is as dit binne die huwelik plaasvind, is die huwelik, in die lig van die sterk seksuele drang by die mens, 'n absolute noodsaaklikheid. Dit is heeltemal onmoontlik om sonder die gawe van onthouding buite die huwelik kuis te lewe (Luther, 1966:9). Die natuurlike seksuele drang bring mee dat elkeen wat met 'n goeie gewete en in die guns van God wil lewe, in die huwelik moet tree (Luther, 1973:27; vgl. De Knijff, 1987:171). Doen hy dit nie, is dit feitlik 'n uitgemaakte saak dat hy in die gruwelike sonde van hoerery sal beland (Luther, 1962:19; 1973:9). Die seksuele drang in die mens is immers sedert die sondeval so sterk dat, hoe 'n mens ook al probeer om dit te weerstaan, dit nogtans onweerstaanbaar bly en uiteindelik sal uitloop op hoerery, owerspel en geheime sondes, want dit word bepaal deur die mens se natuur en nie deur sy keuse nie (Luther, 1962:18).

Luther (1962:45) sê verder dat dit 'n vasstaande feit is dat hy wat weier om te trou, in onsedelikheid sal verval. Hoe kan dit anders wees? God het immers die man en vrou so geskape dat hulle saad produseer om te vermeerder. Waarom sal 'n mens dan nie onsedelikheid voorkom deur middel van die huwelik nie? Daarom beveel God die mens om in die huwelik te tree om sodoende hoerery te voorkom (Luther, 1973:9), want die huwelik is daar as ' $n$ hulp teen onkuisheid. Wie die huwelik ook al gebruik om hoerery te voorkom, het Paulus as sy advokaat en beskermheer (Luther, 1973:13; vgl. Selderhuis, 1994:198). 
Vanselfsprekend beteken dit dat geslagsgemeenskap binne die huwelik ook gereeld moet plaasvind; daarom verwerp Luther die bepaling van die Rooms-Katolieke Kerk dat geslagsgemeenskap op sekere heilige dae of tydens swangerskap nie mag plaasvind nie (Luther, 1962:35-36). Hy gaan selfs so ver om te beweer dat dit volgens Paulus beter is om gebed en vas af te skaal as om jou liggaam so te beheer dat jy dit van jou huweliksmaat weerhou (Luther, 1973:14).

Hoe belangrik gereelde geslagsgemeenskap binne die huwelik volgens Luther is, blyk uit sy aanbeveling (Luther, 1959a:100) dat 'n impotente man met 'n ander man, verkieslik sy broer, moet reël om in die geheim met sy vrou gemeenskap te hê en kinders in haar te verwek, terwyl hulle voorgee dat dit die wettige man se kinders is. As die impotente man dit nie wil doen nie en die vrou se seksuele drang haar verteer, moet sy met 'n ander man trou en na ' $n$ ander plek of land vlug. Daarteenoor, as die vrou weier dat haar man met haar geslagsgemeenskap het, behoort die burgerlike owerheid haar daartoe te verplig of haar dood te maak (Luther, 1962:34). Sy beroof haar man dan immers van die liggaam wat sy self aan hom geskenk het - 'n situasie wat in so 'n mate in stryd is met die huwelik dat sy daardeur eintlik die huwelik ontbind (Luther, 1962:34; vgl. ook 1955c:277-278).

Daarteenoor sê hy dat, ook wat geslagsgemeenskap betref, matigheid in die huwelik nagestreef moet word. 'n Mens moet homself beheers en nie 'n varkhok van sy huwelik maak nie (Luther, 1966:11).

Luther se siening dat geslagsgemeenskap wesenlik sondig is, maar tog verskoonbaar is as dit binne die huwelik plaasvind en daarin ook gereeld moet plaasvind, word deur De Knijff (1987:172) soos volg weergegee:

Het is de grondhouding van 'simul justus et peccator'. Men moet dan ook maar vrolijk en onbekommerd in die zonde leven, als het ware in de zonde zonder zonde zijn. Zo aanvaardt Luther de ganse huwelijkswerkelijkheid met een groot gevoel van realisme.

\subsection{Luther se siening van buite-egtelike geslagsgemeenskap}

Uit die voorgaande kan reeds afgelei word wat Luther se siening van buite-egtelike en dus ook voorhuwelikse geslagsgemeenskap is. As geslagsgemeenskap wesenlik sondig is, maar die sonde verskoon word as 
dit binne die huwelik plaasvind, is die sonde onverskoonbaar as dit buite die huwelik en dus ook voor die huweliksluiting plaasvind; dan word 'n doodsonde begaan (Luther, 1966:10).

Die sterk seksuele drang wat sedert die sondeval in die mens is (Luther, 1966:8), dwing 'n mens om in geslagsgemeenskap daaraan uiting te gee, maar God wil nie hê dat dit buite die huwelik moet plaasvind nie (Luther, 1973:27).

Luther (1966:9) sê uitdruklik dat geslagsgemeenskap buite die huwelik teen die bevel van God is; daarom rus die oordeel van God op die skuldiges. Geslagsgemeenskap buite en dus ook voor die huwelik word nou al deur God gestraf en Hy sal dit sonder twyfel ook op die oordeelsdag straf (Luther, 1959b:366; 1973:30). Buite-egtelike geslagsgemeenskap is immers 'n lewenswyse van brutale heidene wat hulle nie aan God en sy gebod steur nie (Luther, 1959b:358).

Teen persone wat hulle aan voorhuwelikse geslagsgemeenskap skuldig gemaak het, behoort die owerheid, volgens Luther (1967:292), baie streng op te tree: sowel die man as die vrou behoort minstens vir 'n tyd uit die land verban te word. Op dié wyse moet hulle boet vir hulle skanddaad en moet aan ander 'n voorbeeld gestel word sodat hulle kan vrees.

Aan die ander kant betoon Luther (1967:293) wel 'n mate van simpatie met twee jongmense wat geslagsgemeenskap het terwyl hulle van voorneme is om verloof te raak en te trou. Hoewel hulle optrede verkeerd en sondig is, beskou hy dit nie as reg om hulle geslagsgemeenskap as hoerery te bestempel nie omdat daar by hoerery geen voorneme is om te trou nie.

Aan die maagdom van die meisie voor haar troue het Luther hoë waarde geheg. Hy praat daarvan as haar grootste en belangrikste skat (Luther, 1967:292). 'n Meisie wat haar skuldig gemaak het aan voorhuwelikse geslagsgemeenskap, het haar grootste skat versmaai (Luther, 1967:292); hy beskou haar as ' $n$ vrou wat haar eer verloor het en eintlik waardeloos is (Luther, 1967:293).

Positief gestel: daar word van Christen-jongmense verwag om kuis te bly en hulleself te beheers in afwagting op hulle huwelik. Hierdie jongmense moet veral nie die fout maak om te dink dat hulle voor hulle huwelik in 
ongebonde geslagsgemeenskap die lewe kan geniet en eers later 'n groter gehoorsaamheid sal betoon en dan daarvan sal afsien nie. Aan dié wat so dink, sê Luther (1962:44) dat as een uit 'n duisend daarin sou slaag, dit 'n goeie prestasie sou wees. Hy wat daama streef om 'n kuis lewe te lei, moet vroeg daarmee begin. Om dié rede beveel Luther (1962:48) ook aan dat jongmense op 'n vroeë leeftyd moet trou. Die oudste wat 'n man behoort te wees as hy trou, is twintig jaar, en die meisie behoort te trou tussen die ouderdom van vyftien en agtien jaar.

Van mense wat in konkubinaat lewe, sê Luther (1959b:262, 264) dat dit niks anders as 'n lewe van hoerery is nie. Dit het hy gesê tydens die huweliksbevestiging van twee mense wat voorheen in konkubinaat geleef het, maar nie meer kon nie, omdat dit deur die owerheid verbied is (Luther, 1959b:357).

\subsection{Luther se siening van die ongehude staat}

Luther het besondere waardering vir die ongehude staat, maar dan op twee duidelike voorwaardes:

* Eerstens: die betrokkenes moet werklik die gawe van onthouding hê en nie voorgee dat dit so is, terwyl dit in werklikheid nie die geval is nie (Luther, 1973:16, 28).

* Tweedens: hulle moet die gawe van nie aangetrokke wees tot die huwelik nie, gebruik in die besondere diens van die Here en veral om die evangelie te verkondig (Luther, 1962:47).

Die klipharde waarheid waarvoor die Christen egter te staan kom, is die feit dat slegs ' $n$ besonder klein aantal mense die gawe van onthouding ontvang het (Luther, 1974:95). In dié verband noem Luther verskillende getalle, naamlik een uit 'n duisend (Luther, 1962:21); een uit etlike duisende (Luther, 1955a:271); een vir elke honderdduisend getroudes (Luther, 1973:28). Bowendien moet die gawe van onthouding beskou word as niks anders nie as 'n buitengewone wonder van God (Luther, 1962:21;1973:26), en dit moet as sodanig geëer word; daarom moet iemand wat dit ontvang het, homself nie verhef en as beter as ander beskou nie, maar hy moet slegs God daarvoor dank (Luther, 1973:48). 
Wat in Luther se oë egter absoluut fataal is, is dat mense wat nie die gawe van onthouding ontvang het nie, tog in selibaat probeer lewe, want dit kan nie anders as om op ontug en hoerery uit te loop nie (Luther, 1973:28). Op grond hiervan verklaar hy (Luther, 1962:19) dat priesters, monnike en nonne verplig is om hulle ede nie as bindend te beskou as hulle tot die besef kom dat die ordinansie van God om saad te produseer en kinders te kry, 'n sterk dryfkrag in hulle lewe is nie. Geen outoriteit, wet, bevel of eed mag dit wat God in hulle geskep het, weerstaan nie. Indien enigiets dit wel probeer weerstaan, kan 'n mens in elk geval daarvan seker wees dat dit onafwendbaar is dat hulle nie rein sal bly nie maar hulleself sal besoedel met geheime sondes of hoerery. Luther (1955b:274) het dus ook vir Wolfgang Reissenbusch, wat getwyfel het of hy na sy eed om ongetroud te bly, wel in die huwelik mag tree, soos volg aangespoor om so spoedig moontlik te trou: Waarom wag jy nog en hou jy aan om oor die saak te tob? Dit moet, behoort en sal in elk geval gebeur. Hou op om daaroor te dink en gaan doen dit met blymoedigheid. Jou liggaam eis dit. God wil dit en Hy dryf jou om dit te doen. Daar is niks wat jy daaraan kan doen nie.

Omdat dit vir mense wat die gawe van onthouding nie het nie, feitlik onmoontlik is om buite die huwelik kuis te lewe, veroordeel Luther ook die Rooms-Katolieke Kerk wat priesters verbied om te trou (vgl. De Knijff, 1987:170). Hy sê (Luther, 1973:24) dat daar in die hele wêreld geen sonde of skande so groot en omvattend is nie as die een waardeur 'n persoon verbied word om 'n priester te wees of te word omdat hy hom in die heilige huwelik begewe het. En in sy Groot Kategismus (Luther, 1974:95) sê hy veroordelend van die "paapse gespuis, pouse, monnike en nonne" dat hulle niks anders doen nie as om te lieg as hulle beloftes van "ewige kuisheid" aflê:

Niemand het so min liefde en lus tot kuisheid nie as juis hulle wat van oordrewe heiligheid die huwelikstaat vermy en openlik en skaamteloos hoereer of in die geheim nog erger te kere gaan sodat 'n mens daarvan tenugdeins om dit uit te spreek.

Die normale reël is dat alle mense in die huwelik moet tree en dat niemand in elk geval verbied moet word om te trou nie (Luther, 1959b:359). Luther beklemtoon dit by herhaling dat die huwelik deur God ingestel is (Luther, 1959b:358, 359, 364; 1962:38; 1973:19; 1974:94, 95). 


\section{Calvyn (1509-1564) se siening van seksualiteit}

\subsection{Calvyn se siening van geslagsgemeenskap as sodanig}

Dit is nie maklik om Calvyn se siening van seksualiteit onder woorde te bring nie, omdat 'n oppervlakkige oordeel die indruk wek dat daar by hom in dié verband ' $n$ dualisme is.

Enersyds praat Calvyn van geslagsgemeenskap as iets wat op sigself sondig is. Hy sê dat sedert die sondeval alle menslike handelinge met sonde bevlek is, maar dat dit veel meer van geslagsgemeenskap geld as van die ander normale handelinge van die mens, soos eet, drink, ensovoorts. Van geslagsgemeenskap sê Calvyn (1972a:115, 1 Kor. 7:6) immers nie net dat dit sondig is nie, maar ook dat hierdie drang meer as ander drange baie sterk en bykans dierlik is; daar is 'n gebrek of oneerbaarheid daarin (Calvyn, 1972a:115). In 'n preek oor die sewende gebod (Calvyn, 1978:152) verklaar hy dat geslagsgemeenskap beskamend is; dat dit iets is wat op sigself besoedel en vuil is; dat alle mense wat die gawe van onthouding nie het nie, na regte verdien om voor die regterstoel van God aangekla te word; dat die onbeheersdheid wat voortvloei uit die gemis aan die gawe van onthouding, op sigself sleg is en veroordeel moet word. In sy verklaring van Deuteronomium 24:5 (Calvyn, 1985:383) bestempel hy geslagsgemeenskap as iets wat op sigself sondig is ( $\mathrm{vgl}$. Selderhuis, 1994:199).

Andersyds sê Calvyn (1972a:115) dat as geslagsgemeenskap in die huwelik geskied, dit ophou om sonde te wees, of anders gestel, dit word dan nie deur God as sonde toegereken nie. Hy sê selfs dat die geslagsgemeenskap van die man en die vrou in die huwelik 'n suiwer, eerlike en heilige saak is omdat dit 'n suiwer instelling van God is (Calvyn, 1972a:115).

Hoe moet hierdie oënskynlike botsing van gedagtes by Calvyn verklaar word? Wat hy bedoel, kan moontlik die beste soos volg verduidelik word:

Soos Calvyn elders (Inst. 2.1.11 - vgl. Calvyn 1986:364, 365) die woord natuur ten opsigte van die mens in een asem en sonder nadere kwalifikasie in tweërlei betekenis gebruik sodat dit eers die mens na die sondeval en dan die mens voor die sondeval aandui, so is dit waarskynlik ook met sy uitsprake oor geslagsgemeenskap die geval. Dan kom sy siening daarop 
neer dat geslagsgemeenskap soos alle ander menslike handelinge na die sondeval ook met sonde deurtrek is. Omdat geslagsgemeenskap egter reeds deel gevorm het van die huwelik wat God voor die sondeval ingestel het, reken God die mens die sondigheid daarvan nie toe as dit binne die huwelik plaasvind nie. God het immers oorspronklik bedoel dat dit binne die huwelik moet plaasvind.

Dat hierdie verklaring aanvaarbaar behoort te wees, blyk daaruit dat dit reg laat geskied aan verskillende uitsprake van Calvyn in dié verband, onder andere dié in sy verklaring van Genesis 1:18-24 (Calvyn, 1970:7179), Deuteronomium 24:5 (Calvyn, 1985:383) en 1 Korintiërs 7:1-6 (Calvyn, 1972a:110-115) en ook aan sy preek oor die sewende gebod (Calvyn, 1978:152). Hierdie verklaring is ook in ooreenstemming met Rolston III $(1972: 25,26)$ se interpretasie van Calvyn se siening.

\subsection{Calvyn se siening van geslagsgemeenskap in die huwelik}

Volgens Calvyn is die huwelik deur God ingestel en daarom is dit heilig (Calvyn, 1970:76; 1978:144). Verder sorg God self ook vir die instandhouding van die huwelik (Calvyn, 1978:144).

Die doel van die huwelik was aanvanklik om vir mekaar tot hulp te wees (veral die vrou vir die man) en om kinders voort te bring (Calvyn, 1970:72,112; vgl. De Boer, 1976:242-251). Na die sondeval het daar egter 'n verdere 'gebruik' van die huwelik bygekom, en dit is om 'n geneesmiddel teen die kwaal van sinnelike lus te wees (Calvyn, 1970:73; 1972a:111, 112). Hierdie laaste gebruik van die huwelik word deur Calvyn baie sterk beklemtoon (Calvyn, 1972a:111-116; 1972b:208-209; 1978:151-152).

Calvyn se siening van die huwelik hang ten nouste saam met sy siening van geslagsgemeenskap en vloei in 'n seker sin daaruit voort.

In die vorige punt (4.1) is aangedui dat geslagsgemeenskap volgens Calvyn wesenlik sondig is. Indien dit egter binne die huwelik plaasvind, word die sondigheid daarvan verskoon en beskou God dit nie as sonde nie. Vir die gelowiges is die huwelik 'n deksel waarmee die oortreding bedek word sodat die sonde van geslagsgemeenskap nie meer deur God gesien word nie (Calvyn, 1972a:115). Van die sonde van dié geslagsgemeenskap wat binne die huwelik plaasvind, sê Calvyn (1985:383): 
Het kan niet anders of de lust van het vlees zal de verbintenis tussen man en vrouw met een of andere zonde besmetten; welnu, God vergeeft dat niet alleen, maar Hij stelt daar de bescherming van het heilig huwelijk tegenover, opdat wat op zichzelf zondig was niet toegerekend zou worden; ja, zelfs laat Hij voluit toe dat de man en de vrouw van elkaar genieten.

Hierdie siening van Calvyn blyk ook duidelik uit genoemde preek van hom oor die sewende gebod waarin hy verklaar dat die dekmantel van die huwelik daar is om geslagsgemeenskap wat op sigself besoedel, ongewyd en vuil is te reinig en te heilig (Calvyn, 1978:152).

Omdat geslagsgemeenskap sondig is, maar die sonde verskoon word as dit binne die huwelik plaasvind, is almal wat die gawe van onthouding nie het nie, verplig om in die huwelik te tree sodat hulle daarin uiting kan gee aan hulle seksuele drange. Dit is hierdie doel of 'gebruik' wat na die sondeval bygekom het, wat deur Calvyn besonder sterk beklemtoon word (Calvyn, 1972a:112; 1978:151-152).

Vir die meeste mense is dit onmoontlik om sonder die huwelik hulle onbeteuelde luste te bedwing (Calvyn, 1972b:209). Vir hierdie mense wat die prikkelinge van hulle sondige natuur nie kan weerstaan nie, is dit niks minder nie as 'n uitdruklike gebod van die Here dat hulle moet trou (Calvyn, 1972a:111; Inst. 2.8.43 - vgl. Calvyn 1986:544).

Net soos Luther (vgl. 3.2) beskou Calvyn die huwelik in hierdie verband ook as 'n geneesmiddel vir siekes. Hy sê (1978:151) dat die geneesmiddel van die huwelik daar is vir die mense wat hulle nie van geslagsgemeenskap kan onthou nie. Hy noem God selfs die 'goeie dokter' wat die geslagsgemeenskap in die huwelik as geneesmiddel gegee het vir die sondige kwaal van seksuele luste (Calvyn, 1978:152; 1970:73). Dit is feitlik seker dat mense wat die gawe van onthouding nie het nie en tog ook nie in die huwelik tree nie, in hoerery sal verval (Calvyn, 1978:153, 154; 1972b:208, 219).

Hoewel Calvyn toegee dat geslagsgemeenskap geniet mag word (Calvyn, 1985:383), behoort egpare tog nie te dikwels gemeenskap te hê nie (Calvyn, 1970:77). Hulle moet immers oppas om nie hulle huweliksband met onbeheerste en ongebonde wellus te besmet nie (Inst. 2.8.44 - vgl. Calvyn, 1986:545). 
Wat egter van besondere belang is, is dat Calvyn, nog sterker as Luther (vgl. 1962:46), beklemtoon het dat man en vrou op seksuele gebied ten volle mekaar se gelykes is. Volgens De Knijff (1987:176) is Calvyn die eerste persoon in die geestesgeskiedenis van Europa wat die verhouding tussen man en vrou beskryf en verdedig as 'n gelykwaardige heteroseksuele eenheid wat hulle hele bestaan na liggaam en siel omvat. $\mathrm{Al}$ is die man in ander opsigte die hoof van die vrou, op seksuele gebied is hulle ten volle mekaar se gelykes (Calvyn, 1972a:112). De Knijff (1987:176) sê dat die gevoelsgebonde liefdesgemeenskap tussen gelykes vir Calvyn die grondslag en inhoud van die man-vrou-verhouding is, want man en vrou is komplementêre manifestasies van dieselfde wese, naamlik die menslike natuur wat in hierdie dualiteit sy volle eenheid verwerklik.

\subsection{Calvyn se siening van buite-egtelike geslagsgemeenskap}

Calvyn se siening van buite-egtelike seks hang ten nouste saam met sy standpunt oor die huwelik en geslagsgemeenskap in die algemeen. Dit is eintlik heel eenvoudig om uit Calvyn se siening van geslagsgemeenskap en van die huwelik af te lei wat sy siening oor buite-egtelike geslagsgemeenskap is.

As geslagsgemeenskap op sigself sondig is, maar die huwelik bedek die sonde voor God, beteken dit dat geslagsgemeenskap buite die huwelik 'n onbedekte en onverskoonbare skuld voor die aangesig van God is. Die betrokkenes sal as aangeklaagdes en skuldiges voor die regterstoel van God staan (Calvyn, 1978:152).

Met verwysing na die bedekkende en verskonende karakter van die huwelik vir die sonde in geslagsgemeenskap, sê Calvyn (Inst. 2.8.41 - vgl. 1986:542):

Dit is dus duidelik dat enige ander verbintenis buite die huwelik deur Hom vervloek is. Die huweliksverbintenis is juis as ' $n$ noodmiddel ingestel om te verhoed dat ons in teuellose wellustigheid sou uitbars. Laat ons onsself dus nie mislei wanneer ons hoor dat 'n man nie sonder die vloek van God buitehuwelikse gemeenskap met 'n vrou mag hê nie.

Hy sê verder (Calvyn, 1972b:208-209) dat aangesien die geslagsgemeenskap van man en vrou binne die huwelik deur God verorden en geseën is, daaruit volg dat elke ander vorm van geslagsgemeenskap deur Hom verdoem en vervloek is (vgl. Zickgraf, 1970:13). Ook verloofdes 
mag geen geslagsgemeenskap hê voordat hulle huwelik amptelik in die kerk bevestig is nie (Calvyn, 1964:58). Om hoerery te voorkom, waarsku hy ook die ongetroudes om nie soos ongetemde diere op te tree nie, maar om suiwer en rein na liggaam en gees te wees (Calvyn, 1978:146; vgl. ook Zickgraf, 1970:14).

Wat Calvyn se siening oor voorhuwelikse geslagsgemeenskap was, word ook duidelik geopenbaar in die optrede van die burgerlike owerheid in Genève na 1555. In daardie tyd is die teëstanders van Calvyn uit Genève verban. Die maatreëls wat na hulle vertrek daar toegepas is, was die konkrete uitvoering van die beskouings van Calvyn oor die verhouding tussen man en vrou binne en buite die huwelik. Met betrekking tot voorhuwelikse geslagsgemeenskap was die maatreëls volgens Timmer (1974:139-140) die volgende:

Voorechtelijk geslachtsverkeer was verboden. Er werd een gevangenisstraf opgelegd voor deze daad. Een zwanger meisje dat beweerde door haar verloofde te zijn bevrucht, werd niet geloofd. Zij ontving voor haar gedrag de straf die op prostitutie was gesteld, t.w. 6 dagen gevangenisstraf en bij herhaling zou zij onder trompetgeschal door de stad worden geleid. De buitenechtelijk zwangere vrouw moest des zondags na de prediking in de kerk, d.i. in het openbaar om genade smeken aan de predikant. (Vgl. ook Harkness, 1958:130.)

Verloofdes wat voor die kerklike bevestiging van hulle huwelik geslagsgemeenskap het, het hulle blootgestel aan dieselfde strawwe wat bepaal is vir mense wat skuldig is aan owerspel (Calvyn, 1964:58).

Buite-egtelike geslagsgemeenskap is gestraf met nege dae gevangenisstraf plus 'n boete wat bepaal is deur die erns van die oortreding. Calvyn self was egter van oordeel dat die owerspel van getroudes met die dood gestraf behoort te word, hoewel aan hierdie siening van hom in Genève nie uitvoering gegee is nie (Harkness, 1958:130, 131).

\subsection{Calvyn se siening van die ongehude staat}

Calvyn se siening van geslagsgemeenskap bepaal ook sy siening van die ongehude staat. Aan die een kant het hy wel waardering daarvoor omdat die betrokkenes wat die gawe van onthouding het, hulle nie skuldig maak aan die sonde wat - hoewel verskoonbaar - aan geslagsgemeenskap verbonde is nie. Hy praat van maagdelike kuisheid as 'n besondere en 
boonop mooi gawe. Hy gee toe dat die ongehude staat baie nuttig is en ook nie verag moet word nie (Calvyn, 1972a:116, 117).

Aan die ander kant sê Calvyn (Inst. 2.8.43, 1986:544) dat die meeste mense nie in staat is om in seksuele onthouding te lewe nie (vgl. Harkness, 1958:133); daarom verafsku hy die bepaling van die Rooms-Katolieke Kerk dat priesters en nonne nie mag trou nie, want dit gee aanleiding tot monsteragtige skanddade waarvan blatante hoerery die geringste is (Calvyn, 1966:112, 113; 1978:153, 154). Trouens, as Paulus die ongehude staat gevaarlik ag tot op die ouderdom van sestig jaar (1 Tim. 5:9), is dit vermetel van die Rooms-Katolieke Kerk om jongmense in die vurigste tyd van hulle lewe te dwing om 'n gelofte van 'n lewenslange ongehude staat af te lê (Calvyn, 1966:112). Daarom is Calvyn (Inst. 4.12.23 - vgl. Calvyn, 1992:1546) daarvan oortuig "dat 'n verbod teen die huwelik 'n leerstelling van die duiwels is". Hy sê verder (Inst. 4.12.23 - vgl. Calvyn, 1992:1545): "Dat die huwelik vir priesters verbied is, het beslis vanweë goddelose tirannie plaasgevind, nie alleen strydig met God se Woord nie, maar ook strydig met alle billikheid." Hy praat in dié verband van die "stinkende selibaat" by die Rooms-Katolieke Kerk (Inst. 4.12.23 - vgl. Calvyn, 1992:1545).

Vir hierdie verwerping van die huwelik en derhalwe van God se Woord, het die Here die priesters ook gestraf, want die hoerery waartoe dit aanleiding gegee het, noem Calvyn "dierlike verfoeilikhede" (Calvyn, 1978:153) en "monsteragtige skanddade" (Calvyn, 1966:113). Hierdie "mees engelagtige deug van die pousdom" om sekere mense nie toe te laat om te trou nie (Calvyn, 1978:153), het so 'n hoerery en onkuisheid by die priesters tot gevolg gehad dat daar volgens Calvyn (1972a:116-117) geen huis veilig genoeg was ter beskerming teen hulle nie. Hulle het hulle aan sulke onnatuurlike skandes skuldig gemaak dat dit beter is om dit vir ewig te vergeet as om daarna as voorbeeld te verwys.

Uit sy uitlatings oor die ongehude staat kan gesien word hoe sterk die seksuele drang by die mens volgens die oordeel van Calvyn is en wat gebeur as daar nie in die huwelik ontlading kom vir die mense wat hulle seksuele drange nie kan weerstaan nie (Calvyn, 1972a:111). 


\section{Ooreenstemming tussen Luther en Calvyn}

Uit punte 3 en 4 kan duidelik gesien word dat daar 'n groot ooreenstemming tussen Luther en Calvyn is wat hulle beskouings oor die verskillende aspekte van die seksuele lewe van die mens betref - dermate dat hulle dikwels selfs dieselfde terminologie en beelde gebruik. Tog blyk dit uit die voorgaande, en dit word ook deur De Knijf (1987:175-181) bevestig, dat Calvyn die norme van God se Woord vir die seksuele verhouding tussen man en vrou binne en buite die huwelik verder deurgetrek het as Luther.

Dit spreek vanself dat van hierdie byna gelykluidende standpunt ' $n$ groot invloed sou uitgaan op die seksuele lewe van die mense in die Reformatoriese kerke, in elk geval baie groter as wat die geval sou wees as daar 'n duidelike verskil tussen hulle was. Wel het elkeen 'n eie invloedsfeer gehad, maar in die onderskeie invloedsfere is dieselfde siening van die seksuele lewe van die mens ingedra. Die betekenis daarvan mag nie onderskat word nie.

\section{Die betekenis van die Hervorming vir die seksuele lewe}

\subsection{Daar het veranderinge gekom}

By ' $n$ evaluering van die betekenis van die Reformasie vir die beskouing oor en praktyk van die seksuele lewe van die mens het dit mettertyd duidelik geword dat die veranderings wat tot stand gebring is, ingrypender was as wat aanvanklik besef is. Hierdie verandering behels in hoofsaak die volgende:

* Die kerklike reëling van 'n egpaar se geslagsgemeenskap, byvoorbeeld dat dit net op sekere dae en tye mag plaasvind, is met beslistheid verwerp, en dit is aan elke egpaar oorgelaat om self in verantwoordelikheid voor God daaroor te besluit. Daarmee het daar groter vryheid en ruimte gekom vir gereelde geslagsgemeenskap in die huwelik, hoewel die Hervormers nie nagelaat het om in dié verband tot matigheid te maan nie.

* Die openlike erkenning van die seksuele drang in die lewe van elke normale mens wat na uiting in geslagsgemeenskap soek en 
waaraan op wettige wyse binne die huwelik uiting gegee moet word, het nie slegs tot die verwerping van die selibaat gelei nie, maar ook tot die verwerping van die praktyk in die RoomsKatolieke Kerk dat ongetroudes aan getroudes voorskryf hoe hulle seksuele lewe daar moet uitsien. In werklikheid het daar 'n revolusie plaasgevind, want nou was dit nie meer die ongetroudes wat die getroudes aangekla het dat hulle ' $n$ 'abnormale' (sondige) lewe voer nie, maar die getroudes wat hierdie aanklag teen die ongetroudes (priesters, nonne, ens.) gelê het en bowendien hulle blatante hoerery onder die dekmantel van heiligheid genadeloos oopgevlek het. Hierdie 'revolusie' wat die Hervorming bewerk het, het volgens De Knijff (1987:180) tot gevolg gehad dat daar 'n 'desacralisering van de sexualiteit' plaasgevind het en dat die huwelik as uitvloeisel daarvan 'n wêreldlike aangeleentheid geword het, maar dan nie wêreldlik in die sekularistiese sin van die woord nie, maar in die sin dat dit as 'n aspek van die skeppingsorde van God gesien is.

Hierdie veranderings wat met die Hervorming teweeggebring is, het op die lang duur 'n ingrypende betekenis gehad. Bailey (1959:180) dui hierdie betekenis treffend soos volg aan:

Judged in terms of its immediate results, the Reformation proved to be, not the point of departure of a new sexual tradition but the source of fresh differences within that which already existed. Only after the lapse of four centuries is it becoming apparent that the achievements of Luther and Calvin had deeper implications than are suggested by their actual teaching.

\subsection{Die verandering was nie voldoende nie}

Ondanks dit wat in die vorige punt gesê is, kan in aansluiting by bogenoemde uitspraak van Bailey verklaar word dat die Reformasie in die tyd van Luther en Calvyn en in die tyd direk na hulle optrede nie veel verandering gebring het ten opsigte van die beskouing oor en die praktyk van die seksuele lewe van die mens nie. Net soos Augustinus en Thomas van Aquino het ook Luther en Calvyn geslagsgemeenskap as wesenlik sondig beskou, en die houding wat hulle daarteenoor ingeneem het, was basies negatief. Dit is ' $n$ belangrike saak, veral omdat hulle siening van sake in die eeue wat sou volg, 'n groot invloed in die Protestantse kerke sou uitoefen. Hulle sterk negatiewe uitsprake oor seksualiteit en matige 
positiewe uitsprake daaroor was medeverantwoordelik vir die negatiewe houding oor seksualiteit wat in die negentiende eeu 'n hoogtepunt bereik het (De Bruyn, 1982:102-105).

In hierdie verband val dit 'n mens op dat, terwyl die positiewe aspekte van die sesde, agtste en negende gebod in die Heidelbergse Kategismus duidelik aangedui word, daar oor die sewende gebod (Sondag 41) feitlik net op negatiewe wyse oor seksualiteit gepraat word. Hoewel dit wat daarin staan voluit op die Skrif gegrond is, word die positiewe betekenis van die huwelik en van seksualiteit as gawe van God, wat ook in die Skrif aangedui word (vgl. Gen. 29:20-21; Spr. 5:15-19; Pred. 9:9; Hoogl. 7:710; 1 Kor. 7:5; Ef. 5:21-33), nie duidelik genoeg daarin gereflekteer nie (Rinzema, 1972:82-83).

'n Meer positiewe houding van die Hervormers teenoor seksualiteit ooreenkomstig die Woord van God - kon moontlik so 'n invloed op die seksuele lewe van die Christendom gehad het dat die seksuele revolusie nie sou plaasgevind het nie (vgl. Mace, 1970:128-134).

\section{Bibliografie}

AUGUSTINUS, A. 1971a. (Oorspronklik ca. 401.) On the Good of Marriage. (De bono conjugali.) (In Schaff, P. ed. A Select Library of the Nicene and Post-Nicene Fathers of the Christian Church. Vol. 3. Translated by C.L. Cornish. Grand Rapids : Eerdmans. p. 397-413.)

AUGUSTINUS, A. 1971b. (Oorspronklik ca. 422.) The Enchiridion. (De fide, spe et charitate.) (In Schaff, P. ed. A Select Library of the Nicene and Post-Nicene Fathers of the Christian Church. Vol. 3. Translated by J.F. Shaw. Grand Rapids : Eerdmans. p. 237-276.)

AUGUSTINUS, A. 1971c. (Oorspronklik ca. 418.) On the Grace of Christ and on Original Sin. (De gratia Christi, et de peccato originali.) (In Schaff, P. ed. A Select Library of the Nicene and Post-Nicene Fathers of the Christian Church. Vol. 5. Translated by P. Holmes \& R.E. Wallis. Grand Rapids : Eerdmans. p. 214-255.)

AUGUSTINUS, A. 197Id. (Oorspronklik ca. 419.) On Marriage and Concuspiscence. (De nuptiis et concupiscentia.) (In Schaff, P. ed. A Select Library of the Nicene and Post-Nicene Fathers of the Christian Church. Vol. 5. Translated by P. Holmes \& R.E. Wallis. Grand Rapids : Eerdmans. p. 258-308.) 
AUGUSTINUS, A. 1971e. (Oorspronklik ca. 420.) Against Two Letters of the Pelagians. (Contra duas epistolas Pelagianorum.) (In Schaff, P. ed. A Select Library of the Nicene and Post-Nicene Fathers of the Christian Church. Vol. 5. Translated by P. Holmes \& R.E. Wallis. Grand Rapids : Eerdmans. p. 373-434.)

BAILEY, D.S. 1959. Sexual Relation in Christian Thought. New York : Harper \& Brothers.

BARCZAY, G. 1967. Revolution der Moral? Die Wandlung der Sexualnormen als Frage an die evangelische Ethik. Zürich/Stuttgart : Zwingli Verlag.

BRINK, L. 1977. De taak van de kerk bij de huwelijkssluiting; een onderzoek naar de geschiedenis van de kerkelijke huwelijksinzegening, vooral onder het aspect van de sacramentaliteit. Nieuwkoop : Uitgeverij Heuff.

CALVYN (CALVINI), J. (I.) 1964. (Oorspronklik 1547.) Ordonnances sur la police des eglises de la campagne. (In Opera quae supersunt omnia. Vol. Xa. Brunsvigae (Braunschweig) : Schwetschke. p. 51-58.)

CALVYN (CALVIJN), J. 1966. Uitlegging van de pastorale brieven. Uit Latyn vertaal deur $H$. Schroten. Kampen : Kok.

CALVYN (CALVIJN), J. 1970. Genesis - 1. 2de druk. Vertaling deur S.O. Los. Goudriaan : De Groot.

CALVYN (CALVIJN), J. 1972a. Uitlegging op den eersten en tweeden zendbrief van Paulus aan de Corinthiërs. 2de druk. Vertaal deur A.M. Donner. Goudriaan : De Groot.

CALVYN (CALVIJN), J. 1972b. Uitlegging op den zendbrief aan de Hebreën. Vertaal deur A.M. Donner. Goudriaan : De Groot.

CALVYN (CALVIJN), J. 1978. Het gepredikte Woord, preeken van Johannes Calvijn. 3de druk. Deel 4: Preeken over den Dekaloog. Vertaal deur J. Douma en W.H. van der Vegt. Franeker : Wever.

CALVYN, J. 1984. (Inl., Boek 1), 1986 (Boek 2), 1988 (Boek 3), 1992 (Boek 4). (Oorspronklik 1559.) Institusie van die Christelike godsdiens. Vertaal deur H.W. Simpson. Potchefstroom : Calvyn Jubileum Boekefonds.

CALVYN (CALVIJN), J. 1985. Harmonie van de laatste vier boeken van Mozes - 2. Vertaal deur J. van den Heuvel. Kampen : De GrootGoudriaan.

CATHECHISM OF THE COUNCIL OF TRENT. 1947. Cathechism of the Council of Trent for Parish Priests. Issued by Order of Pope Pius V; 10th printing. Translated into English by J.A. McHugh \& C.J. Callen. New York : Joseph Wagner/London: Herder.

COLE, W.G. 1955. Sex in Christianity and Psychoanalysis. New York : Oxford University Press. 
DE BOER, W.P. 1976. Calvin on the Role of Women. (In Holwerda, D.W. ed. Exploring the Heritage of John Calvin. Grand Rapids : Baker Book House. p. 236-272.)

DE BRUYN, P.J. 1982. Voorhuwelikse geslagsgemeenskap: 'n teologiesetiese studie. Potchefstroom : PU vir CHO. (Th.D.-proefskrif.)

DE KNIJFF, H.W. 1987. Venus aan de leiband: Europa's erotische cultuur en christelijke sexuele ethiek. Kampen : Kok.

DESCHNER, K. 1980. De kerk en haar kruis; geschiedenis van de seksualiteit in het Christendom. 2de druk. Uit Duits vertaal deur Elise Marijns. Amsterdam : De Arbeiderspers.

HARKNESS, G. 1958. John Calvin: the Man and His Ethics. 2nd printing. New York : Abingdon Press.

HIERONYMUS. 1912. (Oorspronklik 384.) Letter xxii: to Eustochium. (In Wace, H. \& Schaff, P. ed. A Select Library of Nicene and Post-Nicene Fathers of the Christian Church. Vol. 6. St. Jerome: Letters and Select Works. Translated by W.H. Fremantle. New York : Charles Scribner. p. 22-41.)

HUNTEMANN, G. 1971. Aufstand der Schamlosen: das christliche Ethos angesichts der sexuellen Revolution. Wuppertal : Brockhaus Verlag.

KRAFT, C.H. 1968. Relaxation of Taboos Can Be Healthy. Christian Life, 30(7):55, 86, Nov.

LUTHER, M. 1955a. (Oorspronklik 1524.) Letter to Three Nuns. (In Tappert, T.G., ed. \& transl. Luther: Letters of Spiritual Counsel. London : SCM Press. p. 270-272.)

LUTHER, M. 1955b. (Oorspronklik 1525.) Letter to Wolfgang Reissenbusch. (In Tappert, T.G., ed. \& transl. Luther: Letters of Spiritual Counsel. London : SCM Press. p. 272-275.)

LUTHER, M. 1955c. (Oorspronklik 1528.) Letter to Stephen Roth. (In Tappert, T.G., ed. \& transl. Luther: Letters of Spiritual Counsel. London : SCM Press. p. 277-278.)

LUTHER, M. 1959a. (Oorspronklik 1521.) De Babylonische gevangenschap der kerk. (In Luthers Werken - 1. Vertaling deur C.N. Impeta. Kampen : Kok. p. 13-120.)

LUTHER, M. 1959b. (Oorspronklik 1545.) Sermon at Marriage of Sigismund von Lindenau: Heb. 13:4. (In Pelikan, J. \& Lehmann, H.T. ed. Luther's Works. Vol. 51: Sermons. Translated by J.W. Doberstein. Philadelpia : Fortress Press. p. 357-367.)

LUTHER, M. 1962. (Oorspronklik 1522.) The Estate of Marriage. (In Pelikan, J. \& Lehmann, H.T. ed. Luther's Works. Vol. 45 : The Christian in Society - 2. Translated by W.I. Brandt. Philadelphia : Huhlenberg Press. p. 11-49.) 
LUTHER, M. 1966. (Oorspronklik 1519.) A Sermon on the Estate of Marriage. (In Pelikan, J. \& Lehmann, H.T. ed. Luther's Works. Vol. 44: The Christian in Society - 1. Translated by F.C. Ahrens. Philadelphia : Huhlenberg Press. p. 259-320.)

LUTHER, M. 1967. (Oorspronklik 1530.) On Marriage Matters. (In Pelikan, J. \& Lehmann, H.T. ed. Luther's Works. Vol. 46: The Christian in Society - 3. Translated by F.C. Ahrens. Philadelphia : Huhlenberg Press. p. 11-49.)

LUTHER, M. 1973. (Oorspronklik 1524.) Commentary on 1 Corinthians 7. (In Pelikan, J. \& Lehmann, H.T. ed. Luther's Works. Vol. 28: Commentaries. Translated by E. Sittler. Saint Louis : Concordia Publishing House. p. 3-56.)

LUTHER, M. 1974. (Oorspronklik 1530.) Die Groot Kategismus. Uit Duits vertaal deur L. van der Westhuizen. Kaapstad : Teologiese Seminarie van die Evangeliese Broederkerk in S.A.

MACE, D.R. 1970. The Christian Response to the Sexual Revolution. Nashville/New York : Abingdon Press.

MILES, H.J. 1972. Sexual Understanding before Marriage. London : Lakeland.

PALOCZI-HORVATH, G. 1967. La révolution sexuelle. Gallimard : NRF.

RINZEMA, 1972. De sexuele revolutie: uitdaging en antwoord. Kampen : Kok.

ROLSTON III, H. 1972. John Calvin versus the Westminster Confession. Richmond Va.: John Knox Press.

SELDERHUIS, H.J. 1994. Huwelijk en echtscheiding bij Martin Bucer. Leiden : Groen en Zoon.

THOMAS VAN AQUINO. 1948. Summa Theologica - 3. Translated by Fathers of the English Dominican Province. New York/Boston : Benziger Brothers.

TIMMER, M. 1974. Erotiek in lage landen; een geschiedenis. Kampen : Kok. ZICKGRAF, T. 1970. Die Sexualethik Calvins. München : Universität München. 
